\title{
Старообрядчество Европейского Севера по материалам А. С. Пругавина: эволюция внутриконфессиональных границ
}

\begin{abstract}
Аннотация. В статве рассматриваются взгляды народника и публиииста А. С. Пругавина на старообрядиество и сектантство как часть традииионного общества в Российской империи в последней трети XIX в. Представлены и проанализированы семь схем, обнаруженных автором в личном фонде А. С. Пругавина в Российском государственном архиве литературы и искусств (РГАЛИ). В схемах отражается стремление А. С. Пругавина понять, систематизировать и классифииировать религиознье обвединения в империи. Особое внимание уделяется подробному анализу схем и оббяснению исследовательского подхода народника. А. С. Пругавин в исследованиях религиозности русского народа использовал комплексный подход, рассматривая проблему и с точки зрения истории, и с точки зрения религии. Автор приходит к выводу о том, ито А. С. Пругавин предпринимал неоднократные попытки разобраться в многообразии религиозных движений в России. Исходя из их «вредности», пропагандируемой офиииальной властью и иерковью, народник тем неменее пришел к выводу, что ни старообрядиев, ни приверженцев различных сект никак нельзя было считать чуждым и опасным элементом в составе русского общества.
\end{abstract}

Ключевые слова: старообрядчество, старообрядческие толки, А. С. Пругавин, народничество, Русская православнал церковъ, сектантство, традииионное общество, внутриконфессиональные границы, религиозные объединения, Русский Север.

Review. This article examines the views of the populist and publicist A. S. Prugavin on Old Ritualism and sectarianism and their role in being part of the traditional society of the Russian Empire in the last third of the 19th century. The author discovered seven schemes of A. S. Prugavin in his private paper collection at the Russian State Archive of Literature and Arts (RSALA), which are presented and analysed in this article. The schemes reflect the effort of A. S. Prugavin to understand, systematise, and classify the different religious groups within the Empire. Particular attention is devoted to a detailed analysis of these schemes and to the explanation of the research approach of the named populist. A. S. Prugavin in his research of the Russian people's religiosity used an integrated approach, considering the question both from the point of view of history and from the point of view of religion. The author comes to the conclusion that A. S. Prugavin repeatedly attempted to understand the diversity of the religious movements in Russia. Based on their "harmfulness", as declared by the official authorities and the church, the populist nonetheless came to the conclusion that neither the Old Ritualists nor the followers of various sects should be considered alien or dangerous elements in the composition of Russian society.

Key words: interdenominational divisions, traditional society, sectarianism, Russian Orthodox Church, populism, A. S. Prugavin, Old Ritualist confessions, Old Ritualism, religious groups, Russian North.

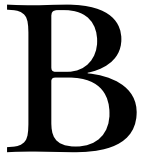
озрождение религиозной жизни пронизывает практически все сферы современного российского общества: происходит восстановление старых и открытие новых обителей Русской православной церкви, школьная программа с 2012 г. [12] предусматривает изучение особого предмета «Основы религиозной культуры и светской этики». Представители иных религиозных конфессий, исторически традиционных для России, также активно включены в жизнь страны как на уровне общества, так и на уровне государства.

Но особая ситуация, сложившаяся в России, способствует не только возрождению духовной жизни, но и выделению особых групп людей по религиозному признаку, которое происходит на фоне политического и экономического расслоения. Во многом причиной возникновения особых религиозных групп становится стремление личности, переживающей духовный кри- 


\section{Исторический журнал: научные исследования № 2 (26) • 2015}

DOI: $10.7256 / 2222-1972.2015 .2 .16092$

зис, защититься таким образом от негативного окружения (общества, государства). И вопрос нетрадиционной религиозности актуален как никогда, несмотря на то что Русская православная церковь пытается вовлечь в духовную жизнь как можно больше граждан.

История России дает возможность увидеть, что подобная ситуация не является новой для страны, религиозная жизнь в которой всегда отличалась разнообразием и динамичностью. Всплески развития и распространения религиозных течений, противопоставлявших себя официальной церкви, на территории Российской империи наблюдались на протяжении всей истории государства. В первом десятилетии XX в., когда в ходе революции 1905 г. были изданы сначала Указ об укреплении начал веротерпимости от 17 апреля 1905 г., а затем Манифест об усовершенствовании государственного порядка от 17 октября 1905 г., общество претерпело разительные изменения. Впервые население империи официально получило позволение «отпадения» от православия. А для представителей других исповеданий были отменены все законодательные ограничения. При этом на деле ситуация для большинства представителей иных религиозных течений не изменилась, гонения и ущемления в правах продолжились.

Именно в 1905 г. представители особого духовного сообщества империи - старообрядцы также получили все права и свободы, в которых они были значительно ограничены ранее: начиная со второй половины XVII в., будучи приравненными к еретикам. Старообрядцы начали активно возрождать и развивать свою духовную культуру, чем и продолжают заниматься в современном российском обществе. Но даже после получения от государства права на свое особое вероисповедание старообрядчество в России не перестало подвергаться притеснениям, т. к. господствующая в империи православная церковь не желала признавать факт наличия достаточно крупной оппозиционной силы.

Что касается сект, за развитием которых Русская православная церковь наблюдала чрезвычайно пристально, то ситуация на рубеже веков также была достаточно сложной. Русский духовный писатель С. В. Булгаков опубликовал в начале XX в. «Справочник по ересям, сектам и расколам» [1], в котором описал более 200 известных на тот момент религиозных направлений. Именно этим справочником мы будем пользоваться для интерпретации религиозных тече- ний. А протоиерей Т. И. Буткевич опубликовал работу «Обзор русских сект и их толков с изложением их происхождения, распространения и вероучения и с опровержением последнего» [2]. Для борьбы с этим ярким проявлением противоборства официальной церкви созывались Всероссийские миссионерские съезды, издавались специальные печатные издания (например, учрежденный в 1896 г. журнал «Миссионерское обозрение», а также «Церковный вестник», «Религиозный вестник»). Несмотря на выход Указа о веротерпимости и некоторую трансформацию методов борьбы с отошедшими от официальной церкви гражданами, в общем и целом ситуация для представителей сект оставалась тяжелой.

В документах из личного архивного фонда А. С. Пругавина в Российском государственном архиве литературы и искусств (РГАЛИ) находится семь схем, в которых автор представил классификацию сект и «дерево раскола». На этих схемах, которые мы приводим далее с его личными пометками, автор пояснял (на наш взгляд, и для себя в том числе) сложные переплетения между старообрядческими толками и сектами, существовавшими на тот момент в Российской империи. Схемы представлены в том же порядке, в котором они располагаются на листах в деле, т. к. это представляется важным для интерпретации взгляда составителя.

Вплоть до революции 1917 г. вопрос о статусе сектантства и старообрядчества часто поднимался как представителями церкви, так и историками, изучавшими это особое явление в русском обществе. Одним из таких исследователей был известный этнограф и публицист последней четверти XIX - начала XX в. Александр Степанович Пругавин. Он еще в конце 1870-х - начале 1880-х гг. заявил о себе постановкой вопроса о необходимости всестороннего исследования раскола и религиозных движений в обществе, опубликовав в газете «Неделя» статью «Знаем ли мы раскол?» $[13,49]$. Безусловно, он не был первопроходцем в изучении этой темы. До него книги и статьи публиковали такие исследователи, как историк и публицист А. П. Щапов, церковный историк Н. Ф. Каптерев, историк и писатель В. Кельсиев, публицист-народник И. И. Каблиц [35, 91]. Заслуга Пругавина состоит в том, что он был одним из первых, кто попытался не просто исследовать вопрос о религиозных движениях в народе, но и проследить эволюцию этих движений, их трансформацию и перетекание из 
одного в другое через несколько переходных форм. Кроме того, А. С. Пругавин был избавлен от присущего многим исследованиям о старообрядчестве и сектантстве недостатка. Он не относился отрицательно к религиозным искателям правды, как некоторые современные ему исследователи, что заведомо положительно сказывалось на качестве его работ, поднимая их на более высокий уровень. Такая позиция объяснялась его принадлежностью к народничеству.

Цель статьи состоит в изучении классификации старообрядческих толков, представленной А. С. Пругавиным в его исследованиях. Т. к. первоначальный интерес к традиционной религиозной жизни народа у автора возник после знакомства именно с таким явлением, как старообрядчество, то основой для рассмотрения в статье будет именно классификация старообрядческих толков и течений. Следует учитывать, что Пругавин не только представил старообрядчество Российской империи как особую христианскую общность страны, но и пытался понять, как и почему произошло разветвление старообрядчества на многочисленные направления, равно как то, каким образом старообрядцы были связаны с сектантством, также процветавшим на обширных территориях страны. Часто он, как и многие его современники, объединял эти два понятия. Поэтому исключить сюжет о старообрядчестве из рассматриваемой интересующей нас темы не представляется возможным, хотя в данной статье освещен он будет в значительной степени сокращенно.

Для достижения поставленной цели необходимо решить следующие исследовательские задачи:

- изучить наследие А. С. Пругавина (статьи, очерки, заметки, книги, архивные материалы), в которых упоминаются старообрядчество и сектантство и их взаимосвязь;

- определить, являлось ли старообрядчество, по мнению А. С. Пругавина, одной из многочисленных сект, существовавших в России, частью христианского мира или чем-то иным.

А. С. Пругавин провел в одном из главных центров поморского раскола Русского Севера городе Кемь - период с марта по ноябрь 1872 г., познакомился там со старообрядцами и сектантами. Он находился под влиянием идей народничества (за что и оказался в ссылке), и оба этих факта - прямое знакомство с религиозными объединениями в обществе и народническая идеология - в дальнейшем во многом повлияли на его взгляды. Так, например, в своих последующих трудах А. С. Пругавин, анализируя причины, по которым старообрядчество в таких масштабах распространилось в империи, предположил, что искать их следует прежде всего в сфере экономической, а не только в духовной.

Важным представляется пояснение, что мы подразумеваем под понятием «Русский Север», т. к. как вопрос этот очень часто поднимается краеведами и регионоведами и интерпретируется по-разному. Ведь сам период пребывания A. С. Пругавина на этой территории, если учитывать его детские и юношеские годы, был достаточно длительным, т. к. родился он в Архангельской губернии.

Трактовка термина «Русский Север» может быть достаточно широкой в зависимости от области исследования и исследователей, которые его используют. Так, в культурно-географическом районировании это понятие связывается с русским фактором, который стал скрепой для огромного пространства страны. Отсюда и название с употреблением прилагательного «русский» - Русский Север - как отражение целостности пространства [3, 139]. Также употребление географического термина «север» в этом названии указывает на ориентацию относительно центра страны. В. Н. Калуцков в работе «Геоконцепты в географии» представил таблицу, отражающую вековое движение в терминологии понятия «Русский Север» $[6,30]$. Он отмечает, что переломным моментом в его продвижении стало создание Архангельского общества изучения Русского Севера в 1909 г.

Однако историко-культурным термином «Русский Север» чаще всего обозначается вся северная территория Европейской части Российской империи, на которой в силу единства социально-экономического и исторического развития и взаимного влияния населения имелись схожие культурно-бытовые особенности. При этом четкого и устоявшегося определения этот термин не имеет, что не позволяет строго заявлять о принадлежности той или иной территории к Русскому Северу. В статье мы будем придерживаться мнения, что под территорией Русского Севера (относительно исследуемого периода, т. е. второй половины XIX - начала $\mathrm{XX}$ в.) понимается прежде всего территория Архангельской и Олонецкой губерний. Именно здесь А. С. Пругавин начинал изучение особенностей религиозных течений в обществе. 


\section{Исторический журнал: научные исследования № 2 (26) • 2015}

DOI: $10.7256 / 2222-1972.2015 .2 .16092$

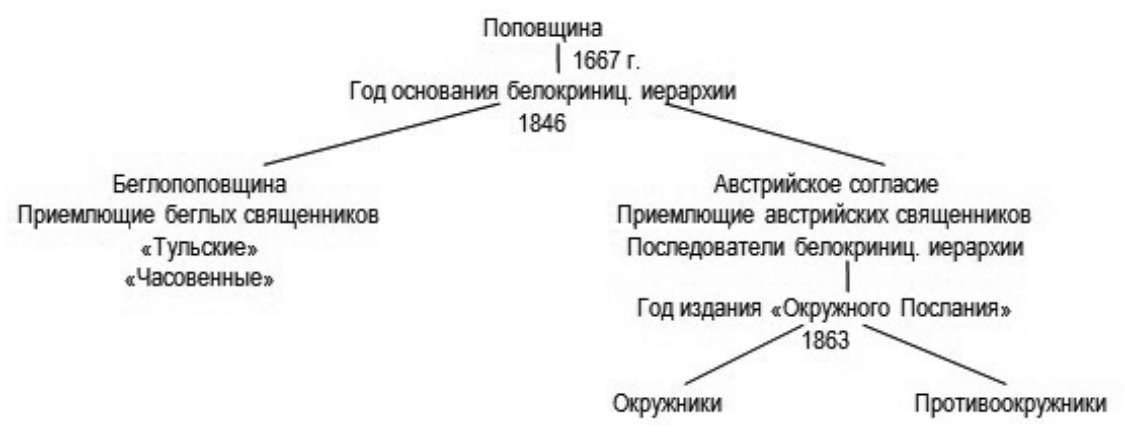

Рис. 1. Схема «Поповщина» (рисунок А. С. Пругавина) [21, л. 98].

Само общество, традиционно проживавшее в данном регионе, также заслуживает более подробного описания. Учитывая обозначенную выше интерпретацию термина «Русский Север», следует сразу отметить, что население этой территории было преимущественно русским. Однако необходимо понимать, что использование прилагательного «русский» в названии региона подчеркивало «не столько преобладание по численности русского населения, сколько его роль в формировании русской культуры и русской идентичности на данной территории» [7, 50]. Здесь проживали как русские, так и коренное население, а именно карелы, вепсы, саамы, поморы. И их общество вплоть до конца XIX в. можно назвать традиционным, если определять понятие «традиционное общество» как общество, регулируемое традицией и не совершившее еще переход к модернизации. Поморы получили широкую известность благодаря их основному промыслу - добыче морского зверя и рыбы. Карелы в столице империи Петербурге присутствовали во многих артелях каменщиков и плотников, т. к. в этом ремесле им часто не было равных.

И во многом своей известностью Русский Север и населявшее его традиционное общество обязаны ссыльным, в частности народникам, которые оказывались там и часто представляли эту территорию как первозданную. Именно они (хотя, безусловно, не только они одни) вели исследования местной жизни, традиций, верований, писали и публиковали статьи и книги. Все их труды основывались прежде всего на присущих им народнических представлениях об окружавшем их обществе, которое, как они считали, было не просто традиционным, а именно первозданным, исходным корнем русского народа. И А. С. Пругавин не стал исключением из этого правила.

После 1879 г., когда с него был снят полицейский надзор, А. С. Пругавин начал активно заниматься публицистической и исследователь- ской деятельностью, опубликовал несколько десятков статей в ведущих газетах и журналах страны: «Русская мысль», «Исторический вестник», «Голос» и других. В период с 1905 по 1909 год вышли его крупные работы - «Раскол вверху. Очерки религиозных исканий в привилегированной среде» [15], «Религиозные отщепенцы. Очерки современного сектантства» [17] и «Старообрядчество во второй половине XIX века. Очерки из новейшей истории раскола» [18], - в которых он изучал духовную жизнь народа неотрывно от жизни социальной, политической и әкономической. И этот подход сделал его работы чрезвычайно популярными: ведь работы его современников, посвященные данной теме, чаще всего освещали вопрос о старообрядчестве в истории России очень узко или односторонне. Таким образом, взгляды А. С. Пругавина, сформированные под влиянием народнической идеологии и личного общения со старообрядцами и сектантами, значительно отличались от взглядов, присущих окружавшему его исследовательскому кругу.

А. С. Пругавин полагал, что «раскол в умах и душах народа» представлял собой особую связь быта и религии, так как помимо материальных нужд «у народа существуют и другие потребности, неудовлетворение которых отзывается на нем также крайне болезненно и печально» $[16,7]$. Само понятие «раскол» как особое явление в русской жизни автор понимал как «совокупность всех вообще религиозно-этических и религиозно-бытовых протестов и разномыслий русского народа» $[16,9]$. А. С. Пругавин включал в это понятие как старообрядчество, так и все существовавшие в обществе секты. Таким образом, он объединял в одном понятии («раскол») все те понятия (старообрядчество, сектантство, ереси), которые тогда еще не имели четкого определения ни в богословской науке, ни в гражданском законодательстве [30]. 
Верования, религии, церкви

DOI: $10.7256 / 2222-1972.2015 .2 .16092$
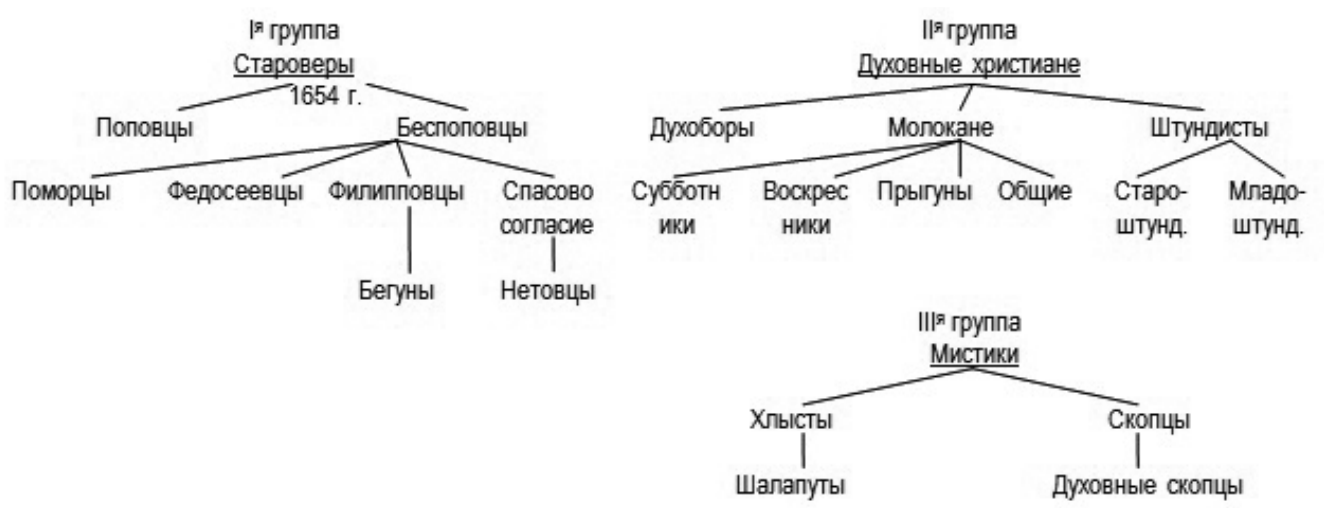

Рис. 2. Схема без заглавия (рисунок А. С. Пругавина) [22, л. 99].

На приведенной выше копии авторского рисунка воспроизведена структура одного из крупнейших течений в старообрядчестве - поповства. К поповским толкам А. С. Пругавин относил «беглопоповцев» и «австрийское согласие», разделяя, в свою очередь, последних на «окружников» и «противоокружников», а у первых выделяя «тульских» и «часовенных» как еще более мелкие течения указанного толка.

В схеме Пругавина есть рубежные даты, которые помогают сориентироваться, на каком основании выделен тот или иной толк. Но представление датировок, на наш взгляд, прочитывается не совсем верно. Так, опираясь на схему, можно предположить, что «беглопоповцы» и «австрийское согласие» возникли параллельно друг другу в 1846 г. Однако известно, что беглопоповцы выделились и оформились как одно из крупнейших старообрядческих течений еще в конце XVII в., в то время как «австрийское согласие» (известное более как «белокриницкое согласие», получившее название от Белокриницкого монастыря в Австрийской империи) возникло почти на два века позже. Как раз в 1846 г. митрополит Амвросий (грек по происхождению) согласился присоединиться к старообрядчеству и стал основоположником старообрядческой иерархии.

Отметил А. С. Пругавин в своей схеме и разделение «австрийского согласия» на «окружников» и «противоокружников», т. к. раскол 60-х гг. XIX в., ознаменованный изданием известного документа «Окружное послание Российских архипастырей Белокриницкой иерархии», привел к распадению на две части этого достаточно крупного течения. Автор приводит это деление, несмотря на то что представители «противоокружников», не принявших «Окружное послание», были очень немногочисленными.
Показательно, что, выделив в «австрийском согласии» два течения, А. С. Пругавин не ввел в схему старообрядцев-поповцев «единоверие» (известное также как «православное старообрядчество»), возникшее еще в первой половине XVIII в. благодаря послаблениям властей и попытке легализации старообрядцев в обществе. Это течение находилось в составе Русской православной церкви, признавая главенство Московского Патриархата и придерживаясь при этом древних богослужебных чинов. В 1800 г. оно было подробно регламентировано «пунктами о единоверии», но при этом не являлось массовым в старообрядческой среде [11, 101-113]. По-видимому, А. С. Пругавин не считал данное течение в старообрядчестве сколько-нибудь значимым, т. к. не знать о нем он не мог.

На рис. 2 представлена схема, которая не была никак озаглавлена А. С. Пругавиным. Повидимому, этот рисунок был одним из многих, на которых автор пытался представить возможные взаимосвязи и пересечения между старообрядчеством и сектантством. Здесь он выделяет три группы в традиционных религиозных движениях в народе: первая группа - староверы, вторая - духовные христиане, третья - мистики. Первая и вторая группы показаны с достаточно большим количеством направлений, тогда как третья - мистики - по сравнению с ними выглядит не столь разветвленной.

К первой группе (самая многочисленная) он отнес все старообрядческие толки, проследив при этом их эволюцию и обособление друг от друга со второй половины XVII в. В старообрядчестве выделено два крупных течения - «поповщина» и «беспоповщина». Это деление было традиционным для исследователей, т. к. эти два толка обособились друг от друга уже к концу 


\section{Исторический журнал: научные исследования № 2 (26) • 2015}

DOI: $10.7256 / 2222-1972.2015 .2 .16092$

XVII в. Особенностью данной схемы является то, что течение «поповщина» подробно не расписано - в отличие от «беспоповщины». А. С. Пругавин выделил в «беспоповщине» четыре согласия: «поморское», «федосеевское», «филипповское»и «спасово». Он привел все крупнейшие толки, оформившиеся к концу XIX в., но не указал рубежные даты и причины разделения. Разделив «беспоповщину» на четыре толка, он упомянул только такие, которые не признавали брак, тогда как толки, приемлющие брак, в указанной схеме никак не отразил (впрочем, он исправил это упущение в еще одной схеме, приведенной далее).

Автор рассматривает все основные старообрядческие толки Русского Севера: федосеевцев, филипповцев, поморцев, которые во многих моментах были взаимосвязаны. Параллельно с ними он выводит «спасово согласие» (или «нетовщина», «козьминщина»), которое возникло отдельно от северных толков в Поволжье в конце XVII в. и представляло собой одно из нескольких самых радикальных старообрядческих согласий, в котором не признавались никакие обряды и службы. При әтом не учитывается тот факт, что название «спасово согласие» к последней трети XIX в. чаще всего относили только к части нетовцев, именуемых еще «глхой нетовщиной». Это и были как раз те, кто не признавал обрядов. А в 40-е гг. XIX в. из нетовцев выделилось еще несколько толков: «новоспасовцы», «поющая нетовщина» (у Пругавина, по-видимому, обозначена в дальнейших схемах как «молельщики», т. к. они признавали часть церковных обрядов) и «отрицанцы» [10, 52-53]. Но данный факт А. С. Пругавин практически оставил без внимания. Возможно, на тот момент информации о делении нетовщины было недостаточно либо различия, характеризующие нетовские толки, были еще не столь четкими.

Приводит А. С. Пругавин и разделение обозначенных течений на еще более мелкие толки, выделив в «филипповском согласии» толк «бегунов» (т. к. основатель толка Евфимий вышел из их среды), а в «спасовом согласии» - «нетовцев» (что, как уже упомянуто выше, не совпадало с традиционной классификацией) [8, 40].

На дальнейших схемах вариант классификации старообрядчества и сектантства, изображенный на рис. 2, будет еще более структурирован и расширен.

В третью группу включены секты в традиционном для конца XIX в. понимании. Это «хлы- сты» (возникновение которых относят к 1645 г., а происхождение названия связывают с одним из обрядов, заключавшимся в хлестании человеком самого себя [33, 86-90]) и «скопцы» (секта, происхождение основателя которой вызывало много споров, была основана в 1772 г., а основной их отличительной чертой стало оскопление). Вероятно, на происхождение этих мистических сект частично оказали влияние протестантизм, масонство, а возможно, и более ранние секты, и даже славянское язычество (такие идеи можно встретить у Афанасия Прокофьевича Щапова в работе «Умственное направление русского раскола», включенной в трехтомное собрание его сочинений, и у Павла Ивановича Мельникова (Андрея Печорского) в труде «Тайные секты», включенном в его Полное семитомное собрание сочинений). Скопцы были признаны в Российской империи уже в период правления Николая I самой вредной сектой, принадлежность к которой могла повлечь за собой серьезные проблемы с властью.

В каждой из этих сект автор также выделяет третий уровень: к «хлыстам» им отнесены «шалопуты», а к «скопцам» - «духовные скопцы». При этом «шалопутов» официальная традиция определяла как тех же хлыстов, «только с некоторыми довольно значительными от них уклонениями», выделившихся довольно поздно, в 1875 г., когда основатель течения крестьянин Порфирий Катасонов объявил себя «живым Богом» [34, 93-94]. Что касается «духовных скопцов», то здесь, по-видимому, имеется в виду трансформация скопческого учения ввиду его строгости и жестоких страданий (непосредственно сама операция оскопления), которые отталкивали многих возможных последователей. Возникла эта новая трактовка скопчества в Румынии в 1872 г., когда стали утверждать, что «можно быть членом скопческой секты без физического оскопления и только оскопив себя духовно», а принять оскопление можно много позже [29, 73-75].

Присутствие в схемах А. С. Пругавина сект наталкивает на мысль о том, что он пытался провести между религиозными учениями, бытовавшими в народе, некие параллели. И, как будет показано далее, он не оставил эту мысль, подробно разрабатывая идею взаимосвязи сект и старообрядчества, а отчасти даже официального православия.

Схема, представленная на рис. 3, расшифровывает первую группу, которую А. С. Пруга- 
Верования, религии, церкви

DOI: $10.7256 / 2222-1972.2015 .2 .16092$

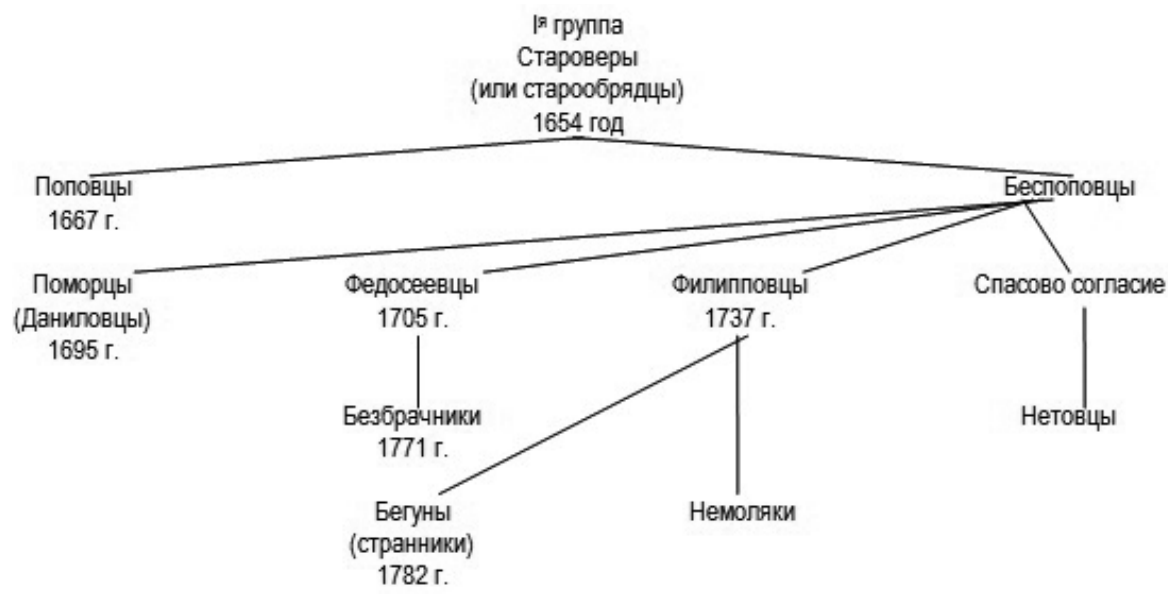

Рис. 3. Схема «Ія группа. Староверы (или старообрядцы)» (рисунок А. С. Пругавина) [23, л. 100].

вин выделял в религиозных течениях русского народа, - «староверов». Тут же, в заголовке к схеме, автором дается и второй термин, которым именовалась эта группа верующих, - «старообрядцы». Аналогично с предыдущей схемой А. С. Пругавин вывел здесь в «беспоповщине» четыре согласия, но допустил более обширное деление на третьем уровне схемы, указав помимо описанных выше «нетовцев» и «бегунов» еще два толка.

Из «федосеевцев» автор выводит «безбрачников», указав рубежной датой возникновения этого толка 1771 г. Такое деление представляется спорным по нескольким основаниям. Вопервых, неясна смысловая нагрузка указанной даты. В 1771 г. у федосеевцев в Москве появилась община (на Преображенском кладбище). В этом же году скончался основоположник учения Феодосий Ковылин [32, 83]. Какие-либо иные значительные моменты, связанные с 1771 г. и историей федосеевского согласия, выявить проблематично. Во-вторых, неясно, почему «безбрачники», согласно схеме, существовали только в рамках федосеевского согласия. У «спасова согласия» в вопросе отношения к браку наблюдались схожие взгляды. Возможно, А. С. Пругавин, указав «безбрачников» в федосеевском толке, имел в виду тот факт, что после смерти его основоположника учение претерпело изменения и появились федосеевцы, приемлющие брак. Но тогда не вполне понятно, почему автор не указывает рядом с «безбрачниками» второе направление толка - «брачников».

Из «филипповцев» помимо «бегунов» (у которых появляется второе название - «странники») Пругавин выделяет еще толк «немоляков», кото- рые ведут свое происхождение от казака Г. Зимина, в 40-е гг. XIX в. обособившего это направление из среды старообрядчества [9, 51-52].

Так же, как и на рис. 3, на указанной схеме не раскрывается направление «поповства», а основное внимание уделяется второму крупнейшему течению старообрядчества - «беспоповству».

Рис. 4 представляет схему одного из старообрядческих течений - «поповщину», - отчасти дублируя рассмотренную ранее схему на рис. 1 . Но, несмотря на повтор части информации (выделяются «беглопоповщина» и «австрийское согласие», последнее делится на два направления), в этой схеме автор вводит новую информацию. Так, размещение этих двух направлений позволяет интерпретировать ее согласно периодам возникновения толков - вначале «беглопоповщина», затем «австрийское согласие». И в этом важное отличие от предыдущей такой же схемы. Вероятно, этот вариант был переосмыслен и доработан А. С. Пругавиным. Важным моментом являются и текстовые пояснения, которые присутствуют в данной схеме, упрощая ее восприятие. Факт наличия довольно подробного текста отличает ее от всех вариантов, рассмотренных ранее.

Схема «Староверческие секты», воспроизведенная на рис. 5, по-видимому, появилась после того, как А. С. Пругавин доработал и свел в одну схемы, представленные ранее на рис. 1, рис. 3 и рис. 4. Здесь представлены очень подробное деление старообрядчества на толки и секты и распределение их по разным направлениям. При этом в данной схеме есть несколько существенных моментов, отличающих ее от предыдущих вариантов. 


\section{Исторический журнал: научные исследования № 2 (26) • 2015}

DOI: 10.7256/2222-1972.2015.2.16092

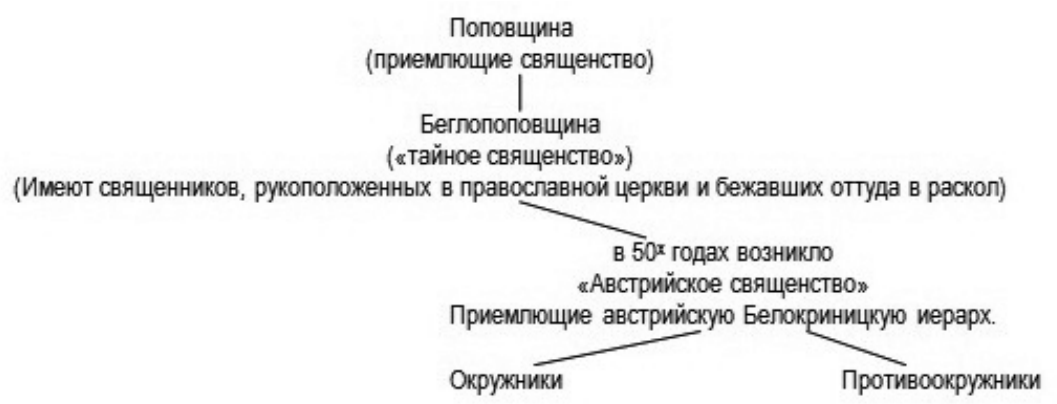

Рис. 4. Схема «Поповщина» (рисунок А. С. Пругавина) [24, л. 105].

Во-первых, рассмотрение «поповцев» представлено в очень сокращенном виде в отличие от схемы на рис. 4. Во-вторых, в беспоповском толке отсутствует «спасово согласие», ранее включавшееся в «беспоповство». В-третьих, появились новые толки, ранее автором не отмечавшиеся. Так, в «беспоповщину» включено «пастухово согласие».

На наш взгляд, самое главное отличие представленной схемы от рассмотренных ранее состоит в том, что А. С. Пругавин впервые сделал попытку обозначить переходный этап от старообрядчества к сектантству, выделив целый блок «переходных» толков в отдельную часть схемы. В этом блоке мы видим «нетовцев» и «немоляков», ранее относимых автором к «беспоповству». По-видимому, он до конца не был уверен в верности и точности своих предшествующих попыток классифицировать эти толки. Кроме уже знакомых названий встречаются и такие, которые автор вводит впервые.

Выделены в отдельную группу следующие наименования: «неплательщики», «воздыханцы», «лучинковцы» и «не-наши». Толк «лучинковцев» по своим особенностям несколько схож и со спасовцами, и с бегунами $[8,40]$, а «воздыханцы» считались выходцами из молокан [4, 20-21], которых, в свою очередь, автор относит уже к рационалистическим сектам. Толчком к появлению секты «неплательщиков» стал Манифест 1861 г., т. к. именно особое толкование этого документа позволило оформиться этой общности. Таким образом, мы можем предположить, что А. С. Пругавин, обособив эту часть схемы, действительно посчитал данные течения переходным звеном между старообрядчеством и сектантством.

Две последние схемы значительно отличаются от предыдущих. На рис. 6, озаглавленном «Классификация сект», А. С. Пругавин разделил все старообрядческие толки и различные секты на три группы: «Старообрядчество», «Мистические секты» и «Рационалистические секты». Вероятно, эта схема могла стать итогом работы со всеми предыдущими, их обзором.

Самой многочисленной стала первая группа, куда автор отнес все старообрядческие течения. Помимо приведенного подробного деления старообрядцев на течения и толки А. С. Пругавин в указанной схеме вновь выделяет в отдельную группу часть толков, т. е. вновь возвращается к идее поиска и выделения момента перехода между старообрядчеством и сектами.

Вторая группа, выделенная в схеме, включала все секты, которые А. С. Пругавин определил как рационалистические. Это наименование встречается впервые. Им было выделено здесь четыре крупных течения: «иудействующие субботники», «духоборцы», «молокане» и «штундисты». «Духоборцы», появившиеся в 60-70-е гг. XVIII в., представляли собой течение, отвергавшее внешнюю обрядность церкви, и идейно во многом были близки к английскому квакерству. Это направление исследователями включается в состав «духовных христиан», которые, как и «молокане», считаются выходцами из духоборчества [5, 46-48]. «Штундисты» изначально были переселенцами из немецких земель, а среди населения юга Российской империи это учение начало распространяться с конца 60-х гг. XIX в. «Субботники», которые, по мнению современников, часть своих догматов приняли из иудаизма, появляются и распространяются в России в период царствования Екатерины II.

Таким образом, в данную группу А. С. Пругавин включил течения сектантства, во многом перекликающиеся с протестантизмом и иудаизмом и заимствовавшие некоторую часть идей оттуда. И выделение этих сект в отдельную группу представляется логичным, т. к. именно в конце XIX - начале XX в. на русское сектантство оказали сильное влияние протестантские организа- 


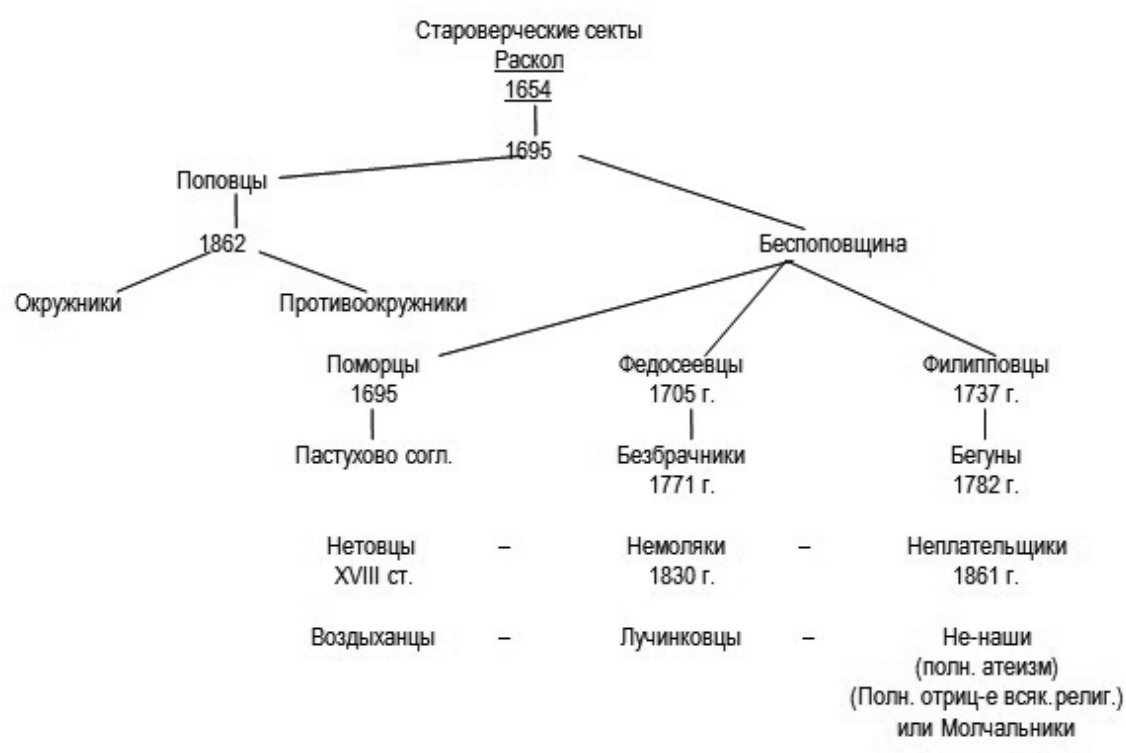

Рис. 5. Схема «Староверческие секты» (рисунок А. С. Пругавина) [24, л. 112].

ции, во многом благодаря появлению на территории империи колоний самих протестантов.

В этой группе А. С. Пругавин также отдельно отмечает несколько сект: «десное братство» (секта, возникшая на Урале, основателем которой был штабс-капитан Николай Ильин), «пашковцы» (секта, возникшая в высших сословиях, основателем которой стал полковник гвардии Василий Пашков), «сютаевцы» (основатель - крестьянин Василий Сютаев). Можно предположить, что он по аналогии с переходом от группы старообрядческих течений к группе рационалистических сект обозначил такой же переход от рационалистических к мистическим сектам, выделив несколько направлений, имевших общие черты.

В третью - самую малочисленную - группу А. С. Пругавин включил секты мистические, где выделил три крупных направления: «хлысты», «скопцы» и «шалопуты». Нечто похожее было представлено ранее (см. рис. 2).

На рис. 7 А. С. Пругавин представил уже «Дерево раскола», на котором самую большую ветвь составили староверы, разделенные на три крупных толка (беспоповцы, поповцы и спасово согласие) и 13 более узких толков. В отдельные небольшие ветви выделены «духовные христиане» («духоборцы», «общие», «штундисты», «воздыханцы», «субботники» и «молокане»), «хлысты или люди Божьи» («шалопуты», «скопцы», «монтане») и «мистические секты». Возможно, автор считал, что мистические секты, хлысты и духовные христиане заимствовали из раско- ла часть своих учений, т. к. озаглавил эту схему именно как «дерево раскола».

Схемы, представленные на рис. 1-7, дают возможность предположить, что автор, несмотря на то что провел за изучением әтой темы немало времени, с большим трудом и большой осторожностью подходил к определению места многочисленных толков старообрядчества и немалого количества старообрядческих сект в собственной классификации. Некоторые из сект и толков у А. С. Пругавина на разных схемах занесены в различные группы. Например, «воздыханцы» отнесены им и к старообрядческим толкам, и к ветви «духовные христиане». Кроме того, на других листах дела также встречаются другие схемы, перечеркнутые рукой Пругавина.

Понятие «секта» в законодательстве Российской империи использовалось в качестве обозначения религиозного течения, которое государство не признавало и даже считало вредным. Т. е. отнесение А. С. Пругавиным старообрядческих течений к сектам во многом можно понять: ведь и старообрядчество вплоть до начала XX в. государство не желало признавать и всячески отвергало возможность его свободного существования.

Крайние даты дела, в котором находятся схемы, составляют 1868-1894 гг., что не позволяет точно предположить, когда именно произошло создание классификаций. Это могло случиться в период, когда А. С. Пругавин разделял идеалы революционного народничества, но также и когда он стал склоняться к правому народ- 


\section{Исторический журнал: научные исследования № 2 (26) • 2015}

DOI: 10.7256/2222-1972.2015.2.16092
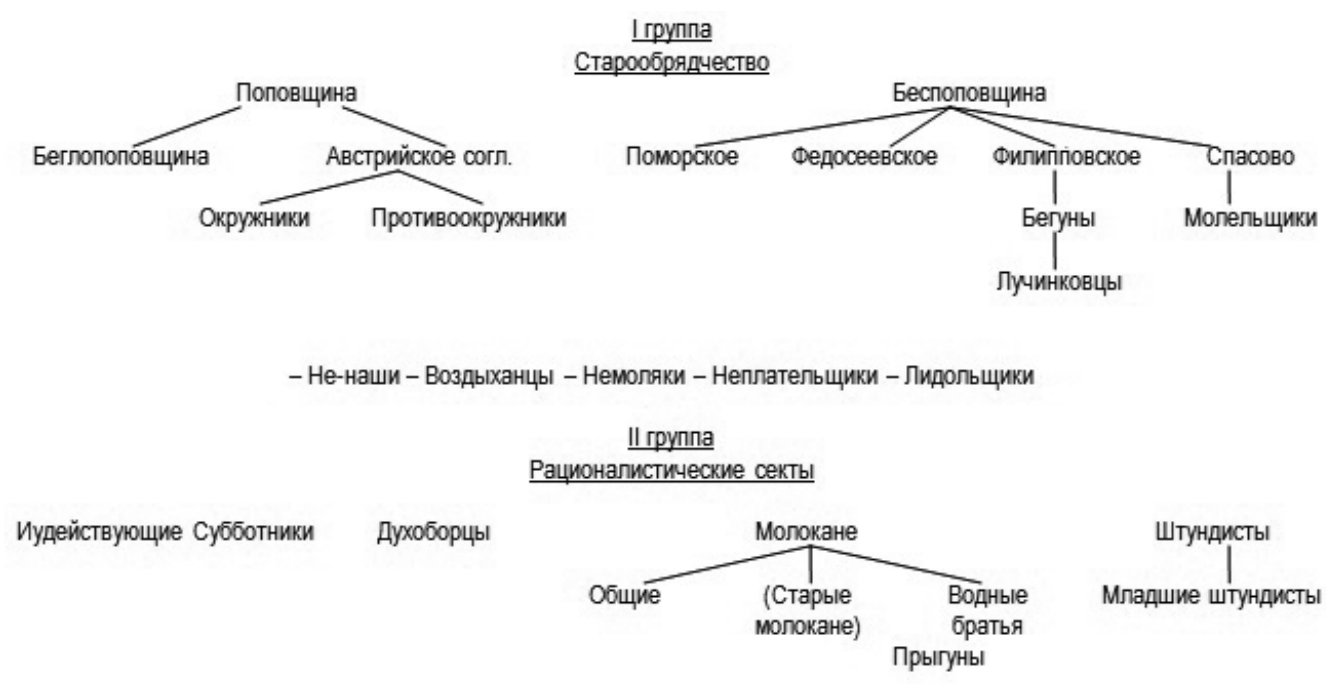

Десное братство - Пашковцы - Сютаевцы -

III группа

Мистические секты

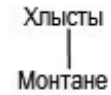

Апостольные общины

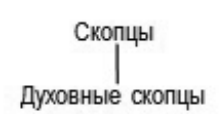

Духовные скопцы
Шалапуты

Скакуны

Рис. 6. Схема «Классификация сект» (рисунок А. С. Пругавина) [26, 113об.-114].

ничеству. Возможно, наиболее вероятен факт создания указанных схем в конце 80 -х - начале 90-х гг. XIX в., т. к. в это время А. С. Пругавин был уже освобожден от надзора полиции, имел возможность продолжать исследовательские занятия и пользоваться накопленным ранее материалом. Подтверждение этой мысли можно увидеть в подписи к одной из схем, в которой значится: «Дерево раскола. Составил А. Пругавин. 1879 год» [28, л. 118].

Кроме того, в книге «Раскол и сектантство в русской народной жизни» автор представил классификацию религиозных течений в русском народе, которая практически полностью повторяла одну из рассмотренных выше схем (см. рис. 6). А. С. Пругавин представил на суд современников классификацию, в которой выделил три главные группы инакомыслия: «секты староверческие, рационалистические и мистические» $[16,77]$. В каждой группе существовало по несколько направлений, но при этом А. С. Пругавин отмечал, что все они часто переплетались между собою. Он пришел к выводу, что при всем разнообразии духовной мысли русского народа рассмотренные им течения «до известной степени составляют одно целое», т. к. подоплекой всех движений ре- лигиозно-этического характера является искреннее стремление народа добиться истины, правды $[14,347]$. И этот факт также дает основание полагать, что схемы, обнаруженные нами в деле 67 его личного фонда, были созданы в последнее десятилетие XIX в., а затем доработаны и опубликованы в одной из работ.

Деятельность А. С. Пругавина по изучению старообрядчества и сектантства в период последней трети XIX - начала XX в. была во многом новой для его современников. Он не просто описывал эти религиозные течения, пытался исследовать их распространение на территории страны, изучить их происхождение и эволюцию, но и пробовал разобраться, а на самом ли деле все они были вредны для государства. Ведь предложенная еще в 1842 г. классификация сект делила их на три группы: «менее вредные», «вредные» и «вреднейшие» [31, 196-199]. Т. е. официальная власть не допускала, что некоторые секты могли не представлять никакой угрозы для империи. И сам термин «секта» в силу особой ментальности русского народа воспринимался в России «менее нейтрально и терпимо, нежели в Европе», очень часто отождествлялся с «ругательнооскорбительным» смыслом [19, 23]. 
Верования, религии, церкви

DOI: $10.7256 / 2222-1972.2015 .2 .16092$

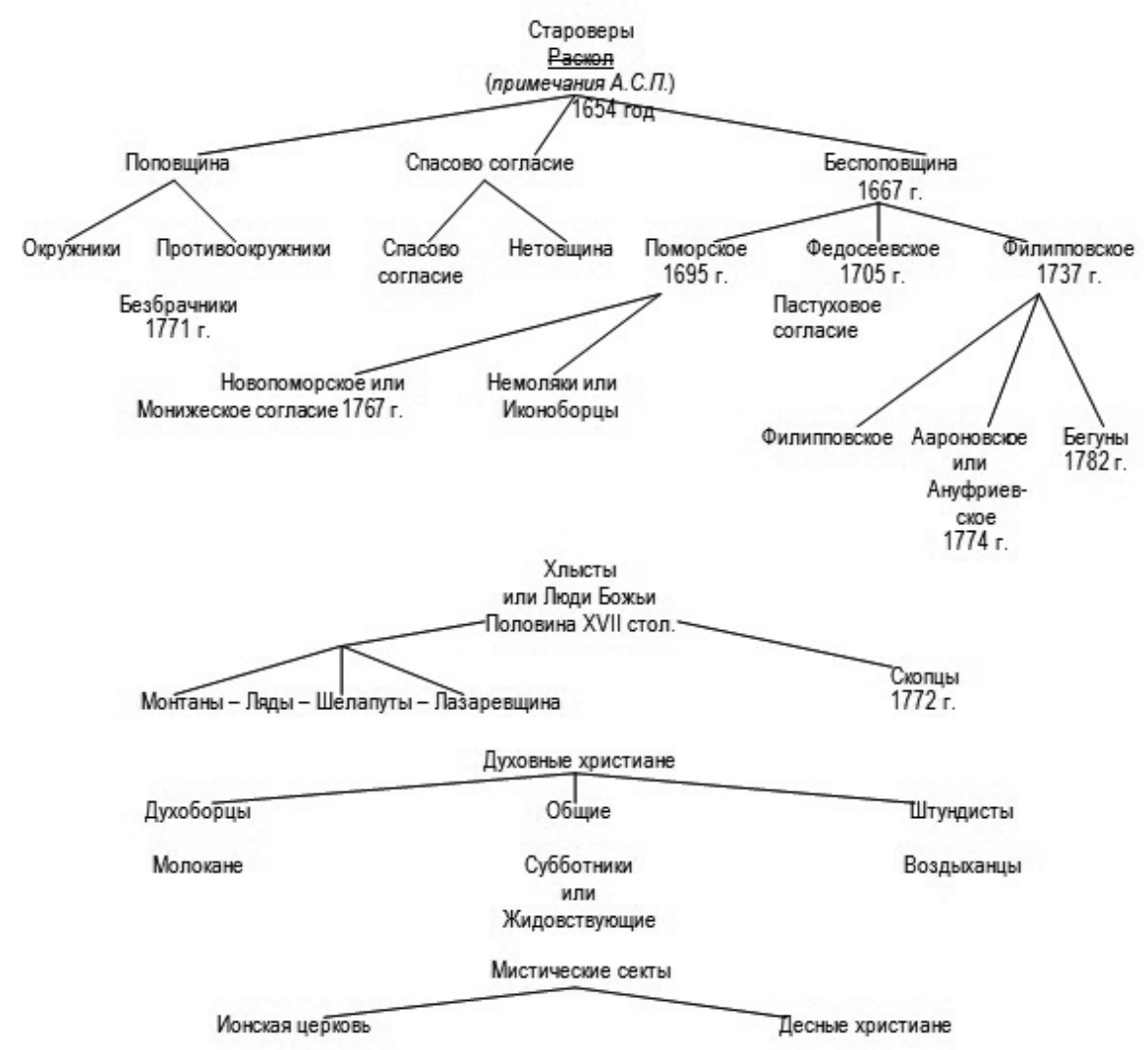

Рис. 7. Схема «Дерево раскола» (рисунок А. С. Пругавина) [27, л. 117об.-118].

Российская империя, сформировавшаяся как полиэтническое государство уже к началу XIX в., к рубежу XIX и XX веков ощутила в полной мере закономерную для таких государств проблему мультиконфессиональности. Но все религиозные течения, существовавшие в империи (а старообрядчество было одним из самых крупных), были неотделимой частью традиционного русского общества, т. к. возникали, развивались, трансформировались и переставали существовать на протяжении всей истории страны. И не учитывать этот факт было нельзя, несмотря на натянутые отношения между Русской православной церковью и этими религиозными течениями.

А. С. Пругавин, один из крупнейших исследователей старообрядчества и сектантства, считал, что старообрядчество может быть определе- но как «оригинальное явление духовной жизни русского народа», и тем самым указывал, что ни приверженцев различных сект, современных автору и во множестве существовавших в Российской империи, ни самих старообрядцев нельзя считать чуждыми в составе русского общества $[17,29]$. Часто именно они составляют наиболее думающую часть народа, т. к. «превосходно знают всю русскую историю и многое другое $<\ldots>$ вполне и хорошо знакомы с положением и естественным разрешением всех наших общественных вопросов и задач» $[16,93]$. А. С. Пругавин в своих исследованиях пытался донести до современников, что именно эти движения в будущем дадут возможность изменить народное сознание. Благодаря их деятельности, возможно, в общество должны быть привнесены новые здоровые идеи и новые жизненные идеалы.

\section{Библиография:}

1. Булгаков С. В. Справочник по ересям, сектам и расколам. М: Современник, 1994. 225 с.

2. Буткевич Т. И. Обзор русских сект и их толков, с изложением их происхождения, распространения и вероучения и с опровержением последнего. Пг.: И. Л. Тузов, 1915. 25 с. 


\title{
Исторический журнал: научные исследования № 2 (26) • 2015
}

\author{
DOI: $10.7256 / 2222-1972.2015 .2 .16092$
}

3. Веденин Ю. А. Опыт культурно-ландшафтного описания крупных регионов России // Культурный ландшафт как объект наследия. М.: Институт Наследия; СПб.: Дмитрий Буланин, 2004. С. 133-148.

4. Воздыханцы // Булгаков С. В. Справочник по ересям, сектам и расколам. М: Современник, 1994. С. 20-21.

5. Воздыханцы // Булгаков С. В. Справочник по ересям, сектам и расколам. М: Современник, 1994. С. 46-48.

6. Калуцков В. Н. Геоконцепты в географии // Культура и гуманитарная география. 2012. Т. 1. № 1. С. 27-36.

7. Калуцков В. Н. Культурно-географическое районирование России для образовательных целей // Вестник Московского университета. Сер. 19. Лингвистика и межкультурная коммуникация. 2014. № 3. С. 49-64.

8. Лучинковцы // Булгаков С. В. Справочник по ересям, сектам и расколам. М: Современник, 1994. С. 40.

9. Немоляки // Булгаков С. В. Справочник по ересям, сектам и расколам. М: Современник, 1994. С. 51-52.

10. Нетовцы. Нетовщина глухая, или спасово согласие // Булгаков С. В. Справочник по ересям, сектам и расколам. М: Современник, 1994. С. 52-53.

11. Правила учреждения единоверия 1800 года // Сведения из трудов перваго единоверческаго съезда в Москве 25-30 октября 1909 года. Б. м. Б. г. С. 101-113.

12. Приказ Министерства образования и науки Российской Федерации (Минобрнауки России) от 18 декабря 2012 г. № 1060 г. Москва «0 внесении изменений в федеральный государственный образовательный стандарт начального общего образования, утвержденный приказом Министерства образования и науки Российской Федерации от 6 октября 2009 г. № 373» // Российская газета. 2013. № 6015 (22 февраля).

13. Пругавин А. С. Знаем ли мы раскол? // Неделя. 1877. № 49-50.

14. Пругавин А. С. Значение сектантства в русской народной жизни // Русская мысль. 1881. № 1. С. 301-364.

15. Пругавин А. С. Раскол вверху. Очерки религиозных исканий в привилегированной среде. СПб., 1909. 267 с.

16. Пругавин А. С. Раскол и сектантство в русской народной жизни. М.: Типография И. Д. Сытина, 1905. 89 с.

17. Пругавин А. С. Религиозные отщепенцы. Очерки современного сектантства. Вып. 1. М., 1906. 266 с.

18. Пругавин А. С. Старообрядчество во второй половине XIX века. Очерки из новейшей истории раскола. М., 1904. 281 с.

19. Пчелинцев А. В. К вопросу о терминах «традиционная религия» и «секта» // Религия и право. 1999. № 2. С. 23-25.

20. Пругавин А. С. Статьи, заметки, схемы о расколе // Российский государственный исторический архив (РГАЛИ). Ф. 2167. Оп. 1. Д. 67. Л. 98

21. Пругавин А. С. Статьи, заметки, схемы о расколе // Российский государственный исторический архив (РГАЛИ) Ф. 2167. Оп. 1. Д. 67. Л. 99

22. Пругавин А. С. Статьи, заметки, схемы о расколе // Российский государственный исторический архив (РГАЛИ) Ф. 2167. Оп. 1. Д. 67. Л. 100.

23. Пругавин А. С. Статьи, заметки, схемы о расколе // Российский государственный исторический архив (РГАЛИ) Ф. 2167. Оп. 1. Д. 67. Л. 105.

24. Пругавин А. С. Статьи, заметки, схемы о расколе // Российский государственный исторический архив (РГАЛИ) Ф. 2167. Оп. 1. Д. 67. Л. 112.

25. Пругавин А. С. Статьи, заметки, схемы о расколе // Российский государственный исторический архив (РГАЛИ) Ф. 2167. Оп. 1. Д. 67. Л. 113об.-114.

26. Пругавин А. С. Статьи, заметки, схемы о расколе // Российский государственный исторический архив (РГАЛИ) Ф. 2167. Оп. 1. Д. 67. Л. 117 об.-118.

27. Пругавин А. С. Статьи, заметки, схемы о расколе // Российский государственный исторический архив (РГАЛИ) Ф. 2167. Оп. 1. Д. 67. Л. 118.

28. Скопцы // Булгаков С. В. Справочник по ересям, сектам и расколам. М: Современник, 1994. С. 73-75.

29. Старообрядчество. Лица, предметы, события и символы. Опыт энциклопедического словаря. М.; Церковь, 1996.317 с.

30. Уложение о наказаниях уголовных и исправительных // Свод законов Российской империи. Т. 15. СПб., 1886. Ст. 196199.

31. Федосеевщина // Булгаков С. В. Справочник по ересям, сектам и расколам. М.: Современник, 1994. С. 83.

32. Хлысты // Булгаков С. В. Справочник по ересям, сектам и расколам. М.: Современник, 1994. С. 86-90.

33. Шалопуты // Булгаков С. В. Справочник по ересям, сектам и расколам. М.: Современник, 1994. С. 93-94.

34. Эткинд А. Русские секты. Non-fiction по-русски правда. Книга отзывов. М.: НЛО, 2007. С. 91-107.

35. Скоробогачева Е. А. Эволюция образа святого Николая Чудотворца в искусстве Русского Севера // Культура и искусство. 2013. № 3. C. 306-313. DOI: 10.7256/2222-1956.2013.03.7.

\section{References (transliterated):}

1. Bulgakov S. V. Spravochnik po eresyam, sektam i raskolam. M: Sovremennik, 1994. $225 \mathrm{~s}$.

2. Butkevich T. I. Obzor russkikh sekt i ikh tolkov, s izlozheniem ikh proiskhozhdeniya, rasprostraneniya i veroucheniya i $\mathrm{s}$ oproverzheniem poslednego. Pg.: I. L. Tuzov, 1915. $25 \mathrm{~s}$.

3. Vedenin Yu. A. Opyt kul'turno-landshaftnogo opisaniya krupnykh regionov Rossii // Kul'turnyi landshaft kak ob"ekt naslediya. M.: Institut Naslediya; SPb.: Dmitrii Bulanin, 2004. S. 133-148.

4. Vozdykhantsy // Bulgakov S. V. Spravochnik po eresyam, sektam i raskolam. M: Sovremennik, 1994. S. 20-21.

5. Vozdykhantsy // Bulgakov S. V. Spravochnik po eresyam, sektam i raskolam. M: Sovremennik, 1994. S. 46-48.

6. Kalutskov V. N. Geokontsepty v geografii // Kul'tura i gumanitarnaya geografiya. 2012. T. 1. № 1. S. 27-36.

7. Kalutskov V. N. Kul'turno-geograficheskoe raionirovanie Rossii dlya obrazovatel'nykh tselei // Vestnik Moskovskogo universiteta. Ser. 19. Lingvistika i mezhkul'turnaya kommunikatsiya. 2014. № 3. S. 49-64. 


\section{Верования, религии, церкви}

DOI: $10.7256 / 2222-1972.2015 .2 .16092$

8. Luchinkovtsy // Bulgakov S. V. Spravochnik po eresyam, sektam i raskolam. M: Sovremennik, 1994. S. 40.

9. Nemolyaki // Bulgakov S. V. Spravochnik po eresyam, sektam i raskolam. M: Sovremennik, 1994. S. 51-52.

10. Netovtsy. Netovshchina glukhaya, ili spasovo soglasie // Bulgakov S. V. Spravochnik po eresyam, sektam i raskolam. M: Sovremennik, 1994. S. 52-53.

11. Pravila uchrezhdeniya edinoveriya 1800 goda // Svedeniya iz trudov pervago edinovercheskago s"ezda v Moskve 2530 oktyabrya 1909 goda. B. m. B. g. S. 101-113.

12. Prikaz Ministerstva obrazovaniya i nauki Rossiiskoi Federatsii (Minobrnauki Rossii) ot 18 dekabrya $2012 \mathrm{~g}$. № 1060 g. Moskva «0 vnesenii izmenenii $\mathrm{v}$ federal'nyi gosudarstvennyi obrazovatel'nyi standart nachal'nogo obshchego obrazovaniya, utverzhdennyi prikazom Ministerstva obrazovaniya i nauki Rossiiskoi Federatsii ot 6 oktyabrya 2009 g. № 373» // Rossiiskaya gazeta. 2013. № 6015 (22 fevralya).

13. Prugavin A. S. Znaem li my raskol? // Nedelya. 1877. № 49-50.

14. Prugavin A. S. Znachenie sektantstva v russkoi narodnoi zhizni // Russkaya mysl'. 1881. № 1. S. 301-364.

15. Prugavin A. S. Raskol vverkhu. Ocherki religioznykh iskanii v privilegirovannoi srede. $S P b ., 1909.267 \mathrm{~s}$.

16. Prugavin A. S. Raskol i sektantstvo v russkoi narodnoi zhizni. M.: Tipografiya I. D. Sytina, 1905. 89 s.

17. Prugavin A. S. Religioznye otshchepentsy. Ocherki sovremennogo sektantstva. Vyp. 1. M., 1906. 266 s.

18. Prugavin A. S. Staroobryadchestvo vo vtoroi polovine XIX veka. Ocherki iz noveishei istorii raskola. M., 1904. $281 \mathrm{s.}$

19. Pchelintsev A. V. K voprosu o terminakh «traditsionnaya religiya» i «sekta» // Religiya i pravo. 1999. № 2. S. 23-25.

20. Prugavin A. S. Stat'i, zametki, skhemy o raskole // Rossiiskii gosudarstvennyi istoricheskii arkhiv (RGALI). F. 2167. Op. 1. D. 67. L. 98.

21. Prugavin A. S. Stat'i, zametki, skhemy o raskole // Rossiiskii gosudarstvennyi istoricheskii arkhiv (RGALI) F. 2167. Op. 1. D. 67. L. 99.

22. Prugavin A. S. Stat'i, zametki, skhemy o raskole // Rossiiskii gosudarstvennyi istoricheskii arkhiv (RGALI) F. 2167. Op. 1. D. 67. L. 100 .

23. Prugavin A. S. Stat'i, zametki, skhemy o raskole // Rossiiskii gosudarstvennyi istoricheskii arkhiv (RGALI) F. 2167. Op. 1. D. 67. L. 105.

24. Prugavin A. S. Stat'i, zametki, skhemy o raskole // Rossiiskii gosudarstvennyi istoricheskii arkhiv (RGALI) F. 2167. Op. 1. D. 67. L. 112.

25. Prugavin A. S. Stat'i, zametki, skhemy o raskole // Rossiiskii gosudarstvennyi istoricheskii arkhiv (RGALI) F. 2167. Op. 1. D. 67. L. 113ob.-114.

26. Prugavin A. S. Stat'i, zametki, skhemy o raskole // Rossiiskii gosudarstvennyi istoricheskii arkhiv (RGALI) F. 2167. Op. 1. D. 67. L. $117 \mathrm{ob} .-118$.

27. Prugavin A. S. Stat'i, zametki, skhemy o raskole // Rossiiskii gosudarstvennyi istoricheskii arkhiv (RGALI) F. 2167. Op. 1. D. 67. L. 118.

28. Skoptsy // Bulgakov S. V. Spravochnik po eresyam, sektam i raskolam. M: Sovremennik, 1994. S. 73-75.

29. Staroobryadchestvo. Litsa, predmety, sobytiya i simvoly. Opyt entsiklopedicheskogo slovarya. M.; Tserkov', $1996.317 \mathrm{~s}$.

30. Ulozhenie o nakazaniyakh ugolovnykh i ispravitel'nykh // Svod zakonov Rossiiskoi imperii. T. 15. SPb., 1886. St. 196-199.

31. Fedoseevshchina // Bulgakov S. V. Spravochnik po eresyam, sektam i raskolam. M.: Sovremennik, 1994. S. 83.

32. Khlysty // Bulgakov S. V. Spravochnik po eresyam, sektam i raskolam. M.: Sovremennik, 1994. S. 86-90.

33. Shaloputy // Bulgakov S. V. Spravochnik po eresyam, sektam i raskolam. M.: Sovremennik, 1994. S. 93-94.

34. Etkind A. Russkie sekty. Non-fiction po-russki pravda. Kniga otzyvov. M.: NLO, 2007. S. 91-107.

35. Skorobogacheva E. A. Evolyutsiya obraza svyatogo Nikolaya Chudotvortsa v iskusstve Russkogo Severa // Kul'tura i iskusstvo. 2013. № 3. S. 306-313. DOI: 10.7256/2222-1956.2013.03.7. 